\section{Para uma compreensão do acontecimento na imprensa}

\author{
Eduardo Luiz Correia*
}

SODRÉ, Muniz. A narração do fato. Notas para uma teoria do acontecimento. Petrópolis: Vozes, 2009. 287p.
MUNIZ SODRÉ

A Narração do Fato
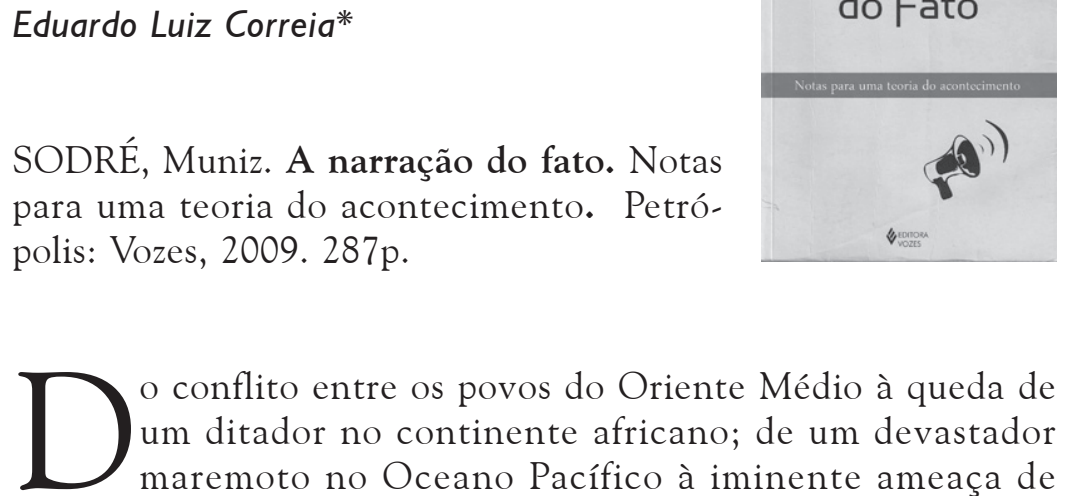

o conflito entre os povos do Oriente Médio à queda de um ditador no continente africano; de um devastador maremoto no Oceano Pacífico à iminente ameaça de contaminação por radiação decorrente de vazamento de uma usina nuclear no Japão. Desta forma, a partir de uma realidade "narrada" em fragmentos de notícias transmitidos pelos meios de comunicação, que nosso mundo é construído, interpretado e, por conseguinte, compreendido. Ou pelo menos, assim pensamos compreendê-lo.

É, portanto, essa elaboração dos discursos narrativos noticiosos dos fatos, a abordagem dos acontecimentos, a responsável pelo nosso contato com a realidade aparente, o mundo tal qual o percebemos. A notícia, e seus consequentes processos de construção, então, surge como elemento estratégico que nos dá sentido ao real, caótico e polissêmico por natureza. E, imerso nesse universo de múltiplas significações do mundo midiatizado de hoje, situa-se um observador, e interlocutor, mais que privilegiado da sociedade: o jornalista, agente mediador - e, portanto, de certa forma discricionário - das instâncias informativas contemporâneas. O jornalista tornou-se o agente responsável por nos contar o que

\footnotetext{
* Docente da Fiam - Faculdades Integradas Alcântara Machado, de São Paulo-SP, Brasil. Doutorando em Comunicação Social pela Universidade de Brasília (UnB). Mestre em Ciências da Comunicação pela Universidade de São Paulo (USP). Graduado em jornalismo pela Universidade Metodista de São Paulo (UMESP) e História, pela Faculdade de Filosofia, Letras e Ciências Humanas da USP.
} 
vai pelos cantos do mundo. O "narrador" do cotidiano, do tempo presente. Mas que confecciona sua narrativa à sua maneira, sob uma perspectiva própria, derivada de uma ótica toda peculiar e inspirada pelo lugar de fala que ocupa na sociedade.

Assim, a realidade com a qual tomamos contato diariamente resulta de uma lógica particular de narrativa, a da imprensa, num espectro mais estreito ou da mídia num caráter mais amplo. Então, todo esse preâmbulo acima pode ser tomado como ponto de partida para uma reflexão mais profunda desse intrincado fenômeno de comunicação que nos envolve e nem sempre, ou quase nunca, nos damos conta. É o que nos permite a leitura de A narração do fato - Notas para uma teoria do acontecimento (Editora Vozes, 2009), do pesquisador e professor da Universidade Federal do Rio de Janeiro, Muniz Sodré. Obra que fornece elementos importantes para a compreensão do funcionamento do complexo universo de formação de sentidos promovido pelos meios, desde suas características fundantes até sutilezas performativas utilizadas pelos jornalistas-narradores do dia a dia.

Ao traçar "uma espécie de radiologia da notícia", conforme a muito apropriada definição feita na apresentação da obra, o autor permite que ao leitor (mesmo aos não-especialistas nos estudos das ciências da comunicação) seja possível fazer uma densa reflexão sobre as várias faces que compõem o processo de construção da notícia, insumo básico de (retro)alimentação das arenas discursivas da cada vez mais complexa sociedade atual. Radiologia, pois, desvela os interstícios da feitura das notícias naquilo que têm de industrial. Mas também, e não menos fundamental, nos seus aspectos compositivos textuais. É quando Sodré discorre sobre as homologias estruturais do texto jornalístico com outras formas narrativas, caso da ficção, de onde resgata os velhos folhetins vindos de uma insurgente imprensa para consumo de massas, ainda no século 18 . Ou abordando a cobertura dos fatos carregados de "humanidade" dos chamados fait divers, que, segundo ele, aproximam "jornal e literatura policial". Uma narrativa policial de ficção cujo "realismo objetivo é o traço de união estilística entre o jornalismo, o romance de investigação e a própria literatura norte-americana high brow, produzida por escritores como Ernest 
Hemingway, John dos Passos, John Steinbeck, Saul Bellows, John Updike, Philip Roth e outros”. Nota-se, desta feita, que a escrita da notícia no jornal guarda bem mais parentesco com a ficção do que muitas vezes podemos perceber.

Neste caminho, entre abordagens sobre acontecimentos e fatos, termos aparentados porém de significados diferentes, Sodré realiza um considerável percurso genealógico do longo processo histórico de uma morfologia da notícia, a qual ele define como "uma construção textual paradigmática da informação jornalística" e a coloca como um "gênero sociodiscursivo". Caminho pelo qual a notícia tal qual a tratamos hoje, com suas rotinas produtivas, inicia-se desde sua concepção, a partir dos moldes fornecidos pela revolução gráfica da era moderna. Época do fenômeno chamado por Edgar Morin de "industrialização do espírito", aquele período que se deu em meio a segunda revolução industrial, quando a imprensa burguesa conquista para si a posição de intérprete público da realidade cotidiana. Ou se autoproclama uma espécie de arauto do tempo presente. Época, aliás, nas quais o ritmo fabril da imprensa mercantil passa a exigir notícias diárias, ou a criar acontecimentos noticiosos com material suficiente para as páginas e páginas dos milhares de jornais saídos das impressoras - com seus horários determinados de produção -, consumidos avidamente por uma população urbana em expansão e sedenta por informação. Tempos nos quais o novo contexto altera significativamente o modo de enxergar o acontecimento jornalístico por parte dos jornalistas, cuja resultante muda forma e conteúdo de narrar as notícias. Situação que, mesmo aperfeiçoada tecnicamente ao longo dos anos, se mantém até hoje no modo de abordar os fatos, narrar o acontecimento - "um 'agregado nominal' de fatos agrupados sob uma mesma designação".

A radiologia feita pelo autor vai mais além de processos produtivos ou comparações estruturais textuais entre jornalismo e ficção. Mergulha, por exemplo, nas profundezas das águas turvas da objetividade positivista do texto jornalístico (segundo ele, uma sutil "estratégia de persuasão"). Turvas, pois não desconsidera, pelo contrário, ressalta as intrínsecas nuances subjetivas performativas nas quais está afundado esse moderno porta-voz da realidade. Ou 
melhor, demonstra a incompatibilidade entre o desejo de objetividade por parte desta "entidade mítica que administra a verdade dos fatos sociais" num campo todo marcado pela subjetividade de seus agentes. Dilema que põe em discussão toda uma percepção da verdade e também a credibilidade do jornal enquanto suporte da notícia - item primordial no item confiabilidade no "contrato" fiduciário entre leitor e narrador (jornalista).

Por fim, tem-se que nesta obra de Muniz Sodré a percepção de como funciona na imprensa o conceito aristotélico de mimeses , "não a imitação da realidade, mas o aproveitamento de aspectos da realidade para produzir um discurso que lhe é semelhante ou homológico". Ou como compreender com profundidade e amplitude todo o universo da imprensa e seus dispositivos de funcionamento no trato do fato jornalístico, da percepção do acontecimento noticioso. Em suma, o jornalismo, essa atividade cada vez mais fundamental na sociedade e certa vez classificada por Antonio Olinto como "literatura sob pressão". 